$\mathrm{DE}$

M E D I C I N A

T R O P I C A L

$\mathrm{DE}$

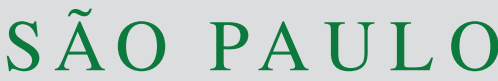

JOURNAL OF THE SÃO PAULO INSTITUTE OF TROPICAL MEDICINE

${ }^{1}$ Empresa Brasileira de Pesquisa Agropecuária, Laboratório de Ciência e Tecnologia de Alimentos, Brasília, Distrito Federal, Brazil

2Universidade de Brasília, Faculdade de Ciências da Saúde, Departamento de Nutrição, Laboratório de Higiene dos Alimentos, Brasília, Distrito Federal, Brazil

${ }^{3}$ Universidade de Brasília, Faculdade de Medicina, Laboratório de Parasitologia Médica e Biologia de Vetores, Brasília, Distrito Federal, Brazil.

${ }^{4}$ Universidade Kroton, Faculdade Anhanguera de Taguatinga, Taguatinga, Distrito Federal, Brazil.

Correspondence to: Eleuza Rodrigues Machado

Universidade de Brasília, Faculdade de Medicina, Laboratório de Parasitologia Médica e Biologia de Vetores, Caixa Postal 4569, Campus Darcy Ribeiro, Asa Norte, CEP 70904-970, Brasília, Distrito Federal, Brazil

Tel: +55 6181971894

E-mail: eleuzarodriguesmachado498@gmail. com; eleuzarodriguesmachado51@gmail.com

Received: 16 September 2018

Accepted: 19 December 2018

\section{Good manufacturing practices of minimally processed vegetables reduce contamination with pathogenic microorganisms}

\author{
Iriani Rodrigues Maldonade ${ }^{1}$, Verônica Cortez Ginani², Roberta Figueiredo \\ Resende Riquette ${ }^{2}$, Rodrigo Gurgel-Gonçalves ${ }^{3}$, Vinícios Silveira Mendes ${ }^{4}$, \\ Eleuza Rodrigues Machado 3,4
}

\section{ABSTRACT}

Consumption of ready-to-eat (RTE) vegetables is quick, easy and healthy, especially when eaten without cooking. However, they might be a source of foodborne pathogenic microorganisms. The objective of this study was to evaluate the microbiological and parasitological contamination of fresh RTE vegetables produced in agroindustries in the Federal District of Brazil (FD), and to correlate contamination with good manufacturing practices (GMP). One hundred and three samples of RTE vegetables were collected from six agroindustries for microbiology and parasitology analyses and correlate with GMP; 54 samples were collected from three hypermarkets for parasitological evaluation. None of the samples analyzed were positive for Salmonella sp. and for thermotolerant coliforms, but they were contaminated with total coliforms. All analyzed samples were contaminated with at least one species of enteroparasistes or commensals, which were identified as Ascaris sp., Balantidium coli, Entamoeba histolytica/dispar, Hookworm, Strongyloides sp., Trichuris sp., Entamoeba sp., eggs and larvae of Nematoda, insects and fungi. Agroindustries that adopted GMP showed less contamination with helminths. RTE vegetables sold in hypermarkets of the FD are unfit for human consumption. It is important to guide farmers in the FD on the need to adopt good practices in the production and processing of vegetables to reduce the microbial contamination.

KEYWORDS: Enteric pathogens. Thermotolerant coliforms. Salmonella sp. Ready-to-eat vegetables. Good manufacture practices.

\section{INTRODUCTION}

The consumption of vegetables is recommended by nutritionists and physicians to obtain a healthy diet due to the nutrients present as vitamins, minerals, and dietary fibers. Considering the nutritional appeal and to attend a growing demand for products ready-to-eat (RTE) companies have specialized in fresh minimally processing vegetables. However, contamination of these plants by bacteria and enteroparasites (protozoa and helminths) is a major public health problem worldwide $^{1-6}$. Some infectious agents may cause morbidity in infected individuals and, in some cases, they may lead to death ${ }^{7}$.

The various steps during the processing of RTE vegetables allow contamination throughout the food chain production, such as planting, harvesting, processing, distribution, and even during consumption. All stages of processing are essential to ensure the quality of the final product, especially considering that once 
contaminated during its cultivation, biofilm formation and/ or internalization of the microorganism may compromise the quality of the final product ${ }^{8-13}$.

Cases of foodborne diseases (FBD) related to fresh food consumption rise worldwide. Thus, to mitigate the risk of FBD and ensure safety food for consumers of RTE vegetables, it is important that good practices are adopted in all stages of production, prioritizing procedures based on Hazard Analysis Critical Control Point (HACCP) principles and good hygiene practice, which include Good Agricultural Practices (GAP) and Good Manufacture Practices (GMP) ${ }^{14,15}$.

To adequate GMP procedures for Brazilian legislation, it is necessary to quantify the presence of indicator microorganisms in the various stages of the process. The standards usually established and accepted in Brazil and worldwide for some microorganisms such as Salmonella sp., responsible for many outbreaks of FBD involving the consumption of RTE vegetables, is absent in $25 \mathrm{~g}$ of the product. However, other bacteria such as thermotolerant coliforms suggest possible fecal and/or environmental contamination. Thus, the results of microbiological tests carried out can reveal possible flaws in the process and serve as a basis for the elaboration of public strategies to reduce the risk of contamination ${ }^{16,17}$.

In addition, the presence of parasites also indicates flaws in product hygiene and is characterized as a serious public health problem worldwide. In this sense, several studies have shown a high frequency of protozoa and helminths of medical interest in leafy vegetables sold in supermarkets and public fairs ${ }^{18-28}$. The main enteroparasites that can be transmitted to humans through ingestion of vegetables are: Cryptosporidium sp., Giardia lamblia, Entamoeba histolyticaldispar, Ascaris lumbricoides, Ancylostomidae, Strongyloides stercoralis, Trichuris sp., Taenia sp. ${ }^{24,27,29-32}$.

All the described situations demonstrate that interventions are necessary to reduce the risk of disease transmission through consumption of fresh RTE vegetables. In this context, complying with the General Principles of Food Hygiene and the Code of Hygienic Practices for Fresh Fruits and Vegetables (CAC/RCP 53-2003) which guide the implementation of GAPs and GMPs is essential.

Although there are many studies evaluating RTE vegetable contamination, only a few have related the contamination with GMP in Brazil ${ }^{33}$, especially in the Midwest region. The objective of this study was to evaluate the contamination of fresh RTE vegetables produced and/ or processed in agroindustries in the surroundings of the Federal District of Brazil (FD) by intestinal parasites (helminths and protozoa) and bacteria and to correlate the findings with GMP.

\section{MATERIALS AND METHODS}

\section{Collection of samples}

The FD is the smallest Brazilian federal unit, located in the Midwest region of Brazil. It is divided into 31 administrative sectors, totaling an area of $5779,999 \mathrm{~km}^{2}$. Among the various activities carried out in the rural areas of the administrative sectors , the production of vegetables stands out.

The agroindustry producers of fresh RTE vegetables included in this study were selected using registration data from the Technical Assistance and Rural Extension Company (EMATER). Samples were collected from six (A, B, C, D, E and F) out of the 10 largest agroindustries, and purchased from three hypermarkets (I, II, and III).

The types of vegetables analyzed were: American Lettuce (AL), Watercress (W), Curly Lettuce (CL), Smooth Lettuce (SL), Red Lettuce (AR), Basil (B), Coriander (CO), Spring Onion (SO), Parsley (P), Arugula (AR), Alfalfa sprout (AS), Kale (K), Bean sprout (BS), Spinach (S), Mint (MT) and Mixed leafy (ML). The samples were obtained according to their availabilities in agroindustries and supermarkets.

According to the statistical sampling plan used by ANVISA $^{34}$, five sample units of each vegetable produced in the agroindustry were collected, with 200 g per sample unit. The samples were stored in the original packaging and transported in refrigerated boxes to the laboratory.

\section{Parasitological analysis}

The collected vegetables samples were sent to the Laboratory of Medical Parasitology and Vector Biology, Pathology Area, Faculty of Medicine, University of Brasilia (UnB). They were weighed and placed in a refrigerator at $4{ }^{\circ} \mathrm{C}$ until processing. Samples $(75 \mathrm{~g})$ were submitted to microbiological analyzes in triplicate and $125 \mathrm{~g}$ were used in parasitological examinations for enteroparasites, arthropods and fungi, following standardized techniques described in the literature ${ }^{28}$.

Samples were considered positive when eggs or larvae of helminth parasites, or protozoan cysts (pathogenic or commensal) were detected. The identification was performed considering their morphological characteristics, as described in the literature. From each sample, $7 \mathrm{~mL}$ of the sediment was analyzed using the depletion process ${ }^{28}$.

For the arthropods, specimens were examined to ensure their integrity or fragmentation, following the instructions described in Ordinance $\mathrm{N}^{\circ}$ 20, September 2009 (Official Gazette of the Federal District, 2009), being considered 
acceptable for consumption when there were only fragments of arthropods up to 15 units per plant, and regarding whole arthropods, up to five insects. For fungi, examinations determined if they were present in samples.

The degree of contamination of RTE vegetables was expressed by the number of specimens found on the slides as follows: + indicates that among the test slides, up to 5 specimens of helminths and protozoa were found; ++ indicates up to 10 specimens; +++ indicates up to 15 specimens; and ++++ indicate more than 15 specimens ${ }^{28}$.

\section{Microbiological analysis}

Samples $(25 \mathrm{~g})$ were transferred to sterile plastic bags and mixed with $225 \mathrm{~mL}$ of $0.1 \%$ peptone water in a Stomacher $400 \mathrm{Lab}-b l e n d e r$ for $1 \mathrm{~min}$. Serial dilutions were prepared in $0.1 \%$ peptone water ${ }^{28}$. Total coliforms and thermotolerant coliforms were enumerated using the most probable number (MPN) method of the American Public Health Association ${ }^{33}$, and the results were expressed as MPN/g. For detection of Salmonella sp., the 3M Petrifilm Salmonella was used ${ }^{28}$. All the samples were analyzed in triplicate.

Identification of critical process points during the production of RTE vegetables

The list used to verify the GMP of industries followed instructions described in the Brazilian legislation ${ }^{35}$. This list, based on principles presented by the Codex Alimentarius, is composed of 164 items, divided into five blocks: 1) Edification and facilities; 2) Equipment, furniture and utensils; 3) Manipulators; 4) Food production and transportation; 5) Documentation.

The items were evaluated and classified as adequate, not suitable or not applicable, according to observations made in loco. According to the legislation and results found, the establishments were classified into three groups: 1) 76 to $100 \%$ attendance of items (satisfactory); 2) 51 to $75 \%$ attendance of the items (satisfactory with restriction); 3) 0 to $50 \%$ attendance of the items (unsatisfactory).

\section{Statistical analysis}

The Kruskal-Wallis test was used to determine significant differences $(\mathrm{p}<0.05)$ among microbial counts in vegetables samples of the six agroindustries and three hypermarkets, using the Statistical Package for Science SPSS $^{\circledR}$, version 17.0 (IBM Corporation, New York, NY).

\section{RESULTS}

A total of 103 sample units of fresh leafy vegetables from the six agroindustries were evaluated (Table 1). Fiftyfour samples collected from three hypermarkets showed the similar contamination values (Tables 2 and 3). Sample units of vegetables (Figure 1) were submitted to microbiological assays in triplicate.

According to the microbiological tests carried out, vegetables did not present Salmonella sp. and no thermotolerant coliforms were observed above $10^{2} \mathrm{MPN} / \mathrm{g}$ (Table 4), levels considered inappropriate for consumption according to the Brazilian legislation. However, the presence of total coliforms ranged from $0.3 \times 10^{1}$ to $1.1 \times 10^{3} \mathrm{MPN} / \mathrm{g}$, and $11.6 \%(\mathrm{n}=12)$ of the samples had a higher count ( $\left.>1.1 \times 10^{3} \mathrm{MPN} / \mathrm{g}\right)$.

Regarding GMP adopted by agroindustries, data collected are in Table 1, which shows the adequacy percentages for each block analyzed, as well as the percentage of adequacy of the total items for each industry.

Statistical analyzes showed that there was a significant difference between the number of total coliforms of leafy

Table 1 - Percentage of evaluation of items of adequacy in relation to GMP in agroindustries of the Federal District, as well as classification according to groups defined by Brazilian legislation ${ }^{16}$.

\begin{tabular}{lccccccc}
\hline Agroindustry & $\begin{array}{c}\text { Buildings } \\
\text { and facilities } \\
(\%)\end{array}$ & $\begin{array}{c}\text { Equipment, } \\
\text { furniture and } \\
\text { utensils (\%) }\end{array}$ & $\begin{array}{c}\text { Food } \\
\text { handlers } \\
(\%)\end{array}$ & $\begin{array}{c}\text { Production and } \\
\text { transport of } \\
\text { food (\%) }\end{array}$ & $\begin{array}{c}\text { Documents } \\
(\%)\end{array}$ & Total (\%) & Group \\
\hline A & 58.1 & 100.0 & 100.0 & 92.3 & 76.5 & 75.9 & 2 \\
B & 81.8 & 93.8 & 100.0 & 88.9 & 71.4 & 86.3 & 1 \\
C & 65.2 & 61.9 & 50.0 & 80.0 & 0.0 & 61.5 & 2 \\
D & 76.0 & 85.7 & 64.3 & 73.3 & 64.7 & 74.5 & 2 \\
E & 63.6 & 52.4 & 42.9 & 59.3 & 0 & 45.3 & 3 \\
F & 84.5 & 100,0 & 100.0 & 96.0 & 100.0 & 91.8 & 1 \\
\hline Total & 71.6 & 81.0 & 75.0 & 81.3 & 59.5 & - & - \\
\hline
\end{tabular}


Table 2 - Species of enteroparasites: helminths or protozoa (pathogenic or commensal) diagnosed in samples of minimally processed leafy vegetables in the Federal District of Brazil by agroindustries.

\begin{tabular}{|c|c|c|c|c|c|c|c|c|}
\hline 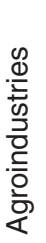 & $\stackrel{*}{\vec{u}}$ & 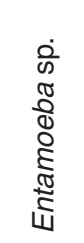 & 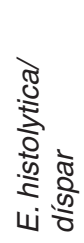 & $\begin{array}{l}\dot{\bar{o}} \\
\dot{0} \\
\ddot{0}\end{array}$ & 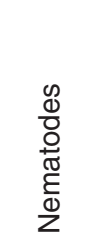 & 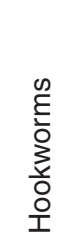 & 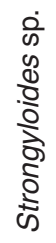 & 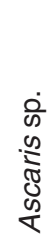 \\
\hline \multirow{6}{*}{ A } & $\mathrm{AL}$ & ++ & - & ++ & ++ & +++ & + & - \\
\hline & $\mathrm{CL}$ & + & - & + & + & ++ & - & - \\
\hline & SL & + & + & - & - & + & - & - \\
\hline & $\mathrm{CO}$ & + & - & - & + & - & - & - \\
\hline & B & + & - & + & + & - & - & - \\
\hline & $\mathrm{ML}$ & ++ & - & + & + & - & - & - \\
\hline \multirow{6}{*}{ B } & $\mathrm{AL}$ & - & - & - & ++ & - & + & - \\
\hline & $\mathrm{CL}$ & ++ & - & - & +++ & + & - & - \\
\hline & $\mathrm{RL}$ & - & - & - & ++++ & + & - & - \\
\hline & $\mathrm{CO}$ & +++ & + & - & ++ & - & - & - \\
\hline & $S$ & ++ & - & - & ++ & - & + & - \\
\hline & MT & ++ & - & + & +++ & - & - & - \\
\hline \multirow{7}{*}{ C } & $\mathrm{AL}$ & - & - & - & - & - & - & - \\
\hline & $\mathrm{CL}$ & - & - & - & + & - & - & - \\
\hline & $\mathrm{RL}$ & ++ & - & - & - & + & - & - \\
\hline & w & + & + & - & + & - & + & + \\
\hline & $\mathrm{CO}$ & - & - & - & ++ & - & + & - \\
\hline & $B$ & - & - & - & +++ & ++ & + & - \\
\hline & $\mathrm{AR}$ & - & - & - & - & - & - & ++ \\
\hline \multirow{4}{*}{ D } & $\mathrm{AL}$ & ++ & - & - & + & - & - & - \\
\hline & $A R$ & + & - & - & - & - & - & - \\
\hline & $\mathrm{CO}$ & - & - & - & - & - & - & - \\
\hline & AS & - & - & - & - & - & - & - \\
\hline \multirow{2}{*}{$E$} & $B$ & ++ & - & - & - & - & - & - \\
\hline & BS & + & - & - & - & - & - & - \\
\hline \multirow{6}{*}{$F$} & $\mathrm{AL}$ & ++ & - & - & ++ & - & - & - \\
\hline & $\mathrm{RL}$ & + & - & + & - & & - & - \\
\hline & so & - & - & - & + & + & - & - \\
\hline & $\mathrm{CO}$ & ++ & + & - & - & - & - & - \\
\hline & B & +++ & - & - & - & - & + & - \\
\hline & AS & - & - & - & ++ & - & - & - \\
\hline
\end{tabular}

${ }^{*}$ American Lettuce (AL), Arugula (AR), Alfalfa sprout (AS), Basil (B), Bean sprout (BS), Coriander (CO), Curly Lettuce (CL), Mint (MT), Mixed leafy (ML), Red Lettuce (RL), Spinach (S), Smooth Lettuce (SL), Spring Onion (SO), Watercress (W). B. coli = Balantidium coli.

samples from the six establishments (Kruskal Wallis $\mathrm{H}$ $(5.103)=18.66628 \mathrm{p}<0.001)$. The highest number of coliforms was observed in RTE vegetables of establishment $\mathrm{E}\left(\right.$ median $\left.=1.1 \times 10^{3} \mathrm{MPN} / \mathrm{g}\right)$ which presented the lowest percentage of adequacy in relation to good practices
$(54.7 \%)$. On the other hand, establishment $\mathrm{F}$ presented $91.8 \%$ adequacy and median number of coliforms was $1.9 \times 10^{1} \mathrm{MPN} / \mathrm{g}$. Figure 2 shows the percentage of inadequacies regarding the adoption of GMP in the analyzed agroindustries. 
Table 3 - Species of enteroparasites: helminths or protozoa (pathogenic or commensal) diagnosed in RTE leafy vegetables obtained from hypermarkets of Brasília, Federal District, Brazil.

\begin{tabular}{|c|c|c|c|c|c|c|c|c|c|}
\hline 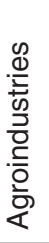 & 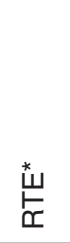 & 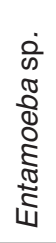 & 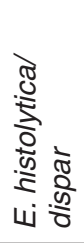 & 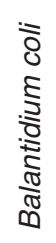 & $\begin{array}{l}0 \\
\frac{0}{0} \\
\frac{0}{0} \\
\tilde{E} \\
\frac{E}{0} \\
z\end{array}$ & 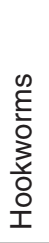 & $\begin{array}{l}\frac{\dot{\theta}}{\infty} \\
\frac{0}{2} \\
\frac{1}{\pi} \\
\frac{\infty}{\square}\end{array}$ & $\begin{array}{l}0 \\
0 \\
0 \\
0 \\
0 \\
0 \\
0 \\
0 \\
0 \\
0 \\
\text { के }\end{array}$ & $\begin{array}{l}\frac{0}{0} \\
\frac{0}{2} \\
\frac{5}{5} \\
\frac{0}{0} \\
\text { is }\end{array}$ \\
\hline \multirow{7}{*}{ I } & $\mathrm{CL}$ & - & - & - & - & - & + & - & - \\
\hline & SL & - & - & - & ++ & - & - & - & - \\
\hline & $\mathrm{RL}$ & ++ & - & - & - & - & - & - & - \\
\hline & CO & ++ & + & - & - & - & - & - & - \\
\hline & so & + & - & - & ++ & - & - & - & - \\
\hline & B & ++ & + & - & - & + & - & - & - \\
\hline & AR & + & - & + & - & - & - & - & - \\
\hline \multirow{7}{*}{ II } & $\mathrm{AL}$ & + & - & - & - & - & - & - & - \\
\hline & $\mathrm{CL}$ & - & - & - & - & - & - & + & + \\
\hline & SL & ++ & + & ++ & + & - & - & - & - \\
\hline & so & - & - & - & - & - & - & - & - \\
\hline & $\mathrm{CO}$ & - & + & - & - & + & - & - & - \\
\hline & $S$ & ++ & - & - & ++ & - & - & - & - \\
\hline & $\mathrm{AR}$ & ++ & + & - & - & - & - & - & - \\
\hline \multirow{4}{*}{ III } & $\mathrm{CL}$ & ++ & - & - & + & - & - & - & - \\
\hline & SL & + & - & - & + & - & - & - & - \\
\hline & $\mathrm{RL}$ & - & + & - & ++ & - & - & - & - \\
\hline & $\mathrm{S}$ & + & - & - & - & - & - & - & - \\
\hline
\end{tabular}

${ }^{*}$ American Lettuce (AL), Arugula (AR), Basil (B), Coriander (CO), Curly Lettuce (CL), Red Lettuce (RL), Smooth Lettuce (SL), Spinach (S), Spring Onion (SO).

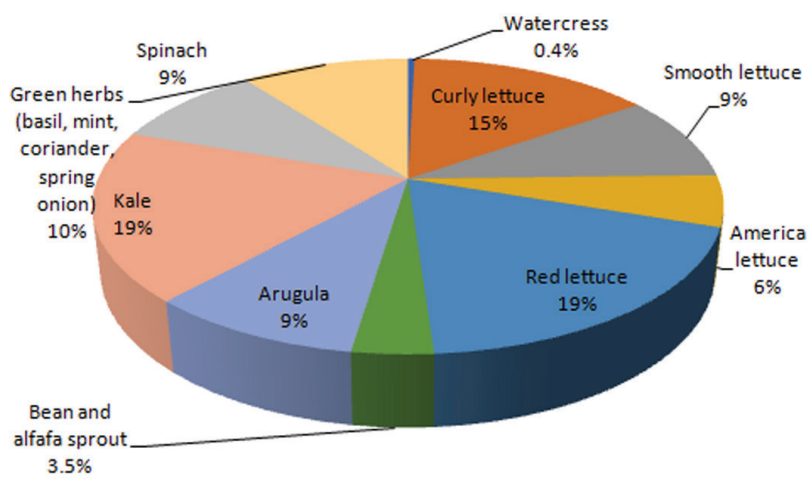

Figure 1 - Distribution of fresh vegetable leafy used to prepare RTE vegetables in agroindustries of Brasilia, Federal District, Brazil.

Regarding the total number of samples obtained in agroindustries (Table 2), 90.3\% were positive for at least one type of enteroparasite, while $94.4 \%$ were positive for the samples purchased in hypermarkets (Table 3). The minimally processed vegetables obtained in the agroindustries and supermarkets were highly contaminated by enteroparasites that are potentially infective to humans such as protozoa: E. histolyticaldispar and Balantidium coli, and the helminth Hookworms, Ascaris sp., Strongyloides sp., Trichuris sp. and many other organisms, such as unidentified nematodes, eggs and larvae.

In almost all positive samples to protozoan enteroparasites belonging to the genus Entamoeba (Table 2 and Table 3), the commensal Entamoeba coli was present in 84 samples obtained in agroindustries, and in 12 samples acquired in hypermarkets. Other species of Entamoeba sp. were present in the samples, but they were not further identified. Insects, whole mites or parts of them and fungi were positive in the 103 samples analyzed (data not shown).

\section{DISCUSSION}

In 2018, the Plant and Animal Products Inspection 
Table 4 - Percentage of samples according to levels of thermotolerant coliforms found (MPN/g)

\begin{tabular}{|c|c|c|c|c|c|c|c|}
\hline \multirow{2}{*}{ Vegetables samples $(n=103)$} & \multicolumn{7}{|c|}{ Count of thermotolerant coliforms (MPN/g) } \\
\hline & $<3$ & 3 & 3.6 & 7.4 & 9.2 & 15 & 43 \\
\hline Smooth lettuce $(n=16)$ & 100 & - & - & - & - & - & - \\
\hline Red lettuce $(n=20)$ & 75 & 5 & 5 & 5 & 5 & 5 & - \\
\hline Curly lettuce $(n=10)$ & 100 & - & - & - & 5 & - & - \\
\hline American lettuce $(n=06)$ & 100 & - & - & - & - & - & - \\
\hline Arugula $(n=10)$ & 40 & - & 30 & 10 & - & 10 & 10 \\
\hline Kale $(n=20)$ & 95 & - & 5 & - & - & - & - \\
\hline Spinach $(n=10)$ & 90 & - & 10 & - & - & - & - \\
\hline Green herbs (basil, mint, chives) $(n=11)$ & 63.63 & 9.09 & - & 9.09 & 18.18 & - & - \\
\hline TOTAL & 83.49 & 1.94 & 5.82 & 2.91 & 2.91 & 1.94 & 0.97 \\
\hline
\end{tabular}

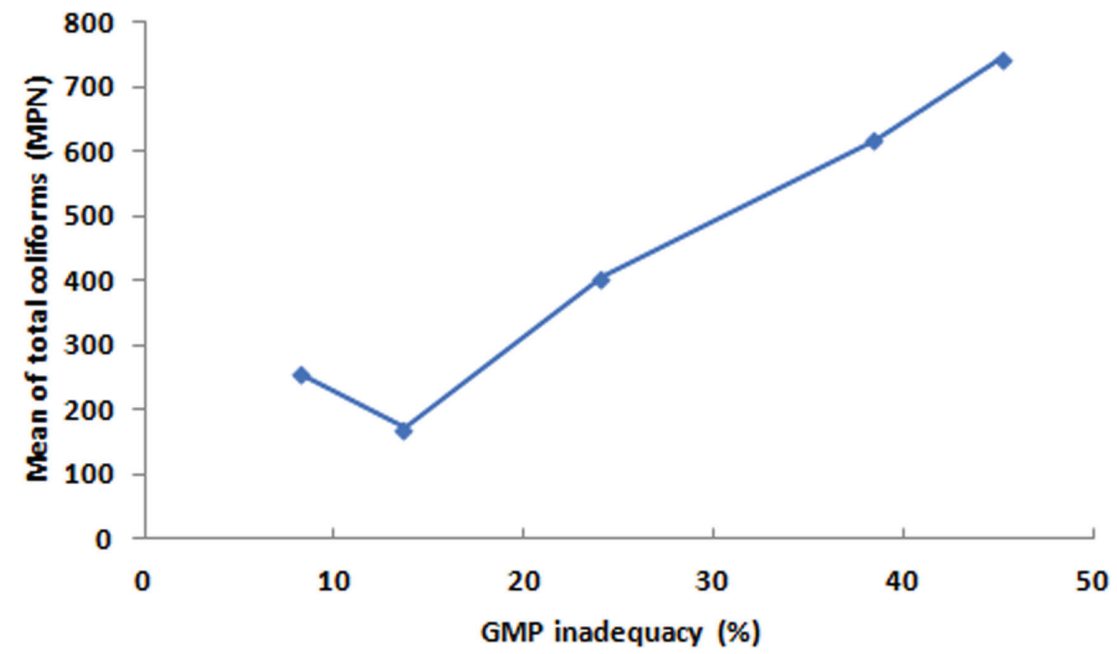

Figure 2 - Relationship between the percentage of GMP inadequacy observed in Federal District agroindustries, and the presence of total coliforms (average values) in RTE vegetables.

Board (DIPOVA) which is the organization responsible for registering products of plant origin, reported that there were ten active agroindustries in the Federal District producing fresh leafy vegetables read-to-eat. In 2017 , the production was $174,848.76 \mathrm{~kg}$. The adoption of GMP is recognized as the most effective way to avoid contamination of food during its production. The procedures adopted in agroindustries can help eliminating or reducing the presence of microorganisms to acceptable levels and ensure that the consumption of RTE vegetables does not result in the risk of an outbreak of FBD, as well as the increase in shelf life ${ }^{35,36}$.

The presence of Salmonella sp. is not usually detected in RTE vegetables, as revealed by several studies ${ }^{37}$. The results show that there is concern about adopting GMPs by the agroindustries studied, but still in an incipient way. The high percentage (81.0 and $81.3 \%$, respectively) of adequacy for the "Production and Transport of Food" blocks and "Equipment, furniture and utensils" reveals that there were investments in crucial parts of the production chain that may have contributed to the bacteriological contamination levels of the analyzed samples, but are still insufficient.

In a study carried out in an agroindustry in Portugal, bacterial species capable of producing virulence-related molecules, as well as potentially biofilm-forming isolates were found in significant quantities in areas considered Critical Control Points (CCP) because they did not present a later stage capable of eliminating or reducing bacteria to safe levels ${ }^{38}$.

In this study, it was observed that the expected direct relationship between GMP and the presence of indicator microorganisms was sensitive to the presence of bacteria. The actions adopted by the agroindustries were able to reduce these microorganisms to safe levels. However, there is a greater fragility of this limit in relation to parasites. This fact can be explained by the higher ubiquity of the agents, as well as the use of more effective methods of elimination 
and/or reduction of bacteria, but with limitations in relation to parasites.

Santos and Biondi ${ }^{26}$ showed parasitic contamination in 17 of the 206 samples $(8.2 \%)$ of vegetables obtained from different establishments (restaurants, fairs and markets) in the FD. In this study, Trichuris sp., Strongyloides sp., Taenia sp., and Giardia sp. were detected in vegetables sold at fairs. In addition Entamoeba sp., E. coli, Strongyloides sp. Ascaris sp, Enterobius vermicularis and Ancylostomidae were detected in vegetables commercialized in markets from $\mathrm{FD}^{29}$. These authors recommended the monitoring of contamination of vegetables sold in establishments in the FD. Another study carried out in Brazil on the presence of enteroparasites and bacteria in vegetables marketed in different Public Supply Centers (CEASA) showed a high degree of contamination of products distributed in these places, by species of helminths, protozoa and also the presence of enterobacteria ${ }^{28}$.

It is estimated that there is a significant reduction in parasitic diseases worldwide. However, the regional and global impact of food-borne parasites remains high and worrisome, especially among vulnerable population groups. The parasitological results observed in the present study corroborate these data, since when considering the large Brazilian territorial dimension and the local differences, it is perceived that conditions favorable to the contamination of vegetables by parasites are perpetuated ${ }^{35,36}$.In addition, there is evidence that the different procedures required in the production of RTE vegetables facilitate cross contamination of large amounts of food, from a small portion of contaminated product. In this way, the existence of a production line without crosses, a production line with adequate structure, equipment, furniture and utensils that meet the specifications that help reducing contaminants (smooth surface, in adequate state of conservation) $)^{17,39}$, are essential to produce safe food. The concern with the transport should be persistent in the adopted GMP, ensuring that there is no risk to food after shipping. In case of building and facilities investments, financial resources are often not available, mainly considering the shifts, highlighting that these items presented a $71.6 \%$ adequacy percentage as described in the literature ${ }^{37}$.

The guarantee of standardized procedures through documentation presented a percentage of adequacy equivalent to $59.5 \%$, demonstrating the fragility of procedures that can be altered by adverse circumstances. Failure to standardize procedures may result in cross contamination, sanitized products during cutting, packaging and washing. Thus, all stages of processing are essential to ensure the final product quality. However, all steps have
CCPs, which must be monitored and controlled to allow the reduction of contaminant levels through the implantation of GMP.

\section{CONCLUSIONS}

The contamination level of the minimally processed vegetables was high in all the establishments: agroindustries and hypermarkets of FD, by enteroparasites: helminths and protozoa pathogenic or commensal, by whole arthropods and/or parts of them. The values were above permitted by Ordinance $\mathrm{n}^{\circ} 20$ (2009), thus unsatisfactory for consumption. Regarding thermoresistant coliforms, it was observed that $11.6 \%$ were unfit for consumption, according to RDC 12, but with absence of Salmonella sp.

The good practices adopted in the hygiene of vegetables minimally processed by agroindustries were not satisfactory to guarantee the absence of pathogenic microorganisms. However, a positive correlation was observed between the good practices adopted with lower contamination rate corresponding to better product reliability.

The results of the present study suggest that in the near future, new researches should investigate the source of contamination of the vegetables in the FD, so that programs and measures to control these sources of contamination can be prepared and implemented to reduce or eliminate sources of human infection by enteroparasites such as fungi, insects and mites from minimally processed vegetables.

\section{ACKNOWLEDGMENTS}

The authors kindly acknowledge the Conselho Nacional de Desenvolvimento Científico e Tecnológico (CNPq) for financial support. The authors also wish to thank the Technicians of EMATER-DF (Technical Assistance and Rural Extension Company) for their technical support.

\section{AUTHORS' CONTRIBUTIONS}

Iriani Rodrigues Maldonade: study design,vegetable samples collection, writing and translation of article into English; Verônica C. Ginani: study design, microbiological examinations and organization of the article. Roberta F. R. Riquette: collection of samples and microbiological tests; Vinícios S. Mendes: sample processing and parasitological examinations; Rodrigo Gurgel-Gonçalves: helped in writing and reviewing the article; Eleuza Rodrigues Machado: study design, parasitological examinations, organization of results, article writing and review of the English usage. 


\section{REFERENCES}

1. Oliveira CA, Germano PM. Estudo da ocorrência de enteroparasitas em hortaliças comercializadas na região metropolitana de São Paulo, SP, Brasil. I - Pesquisa de helmintos. Rev Saude Publica. 1992;26:283-9.

2. Shahnazi M, Jafari-Sabet M. Prevalence of parasitic contamination of raw vegetables in villages of Qazvin Province, Iran. Foodborne Pathog Dis. 2010;7:1025-30.

3. Ebrahimzadeh A, Jamshidi A, Mohammadi S. The parasitic contamination of raw vegetables consumed in Zahedan, Iran. Health Scope. 2013;1:205-9.

4. Gabre RM, Shakir A. Prevalence of some human enteroparasites in commonly consumed raw vegetables in Tabuk, Saudi Arabia. J Food Prot. 2016;79:655-8.

5. Kuan CH, Rukayadi Y, Ahmad SH, Wan Mohamed Radzi CW, Thung TY, Premarathne JM, et al. Comparison of the microbiological quality and safety between conventional and organic vegetables sold in Malaysia. Front Microbiol. 2017;8:1433.

6. Mikhail AF, Jenkins C, Dallman TJ, Inns T, Martín AI, Fox A, et al. An outbreak of Shiga toxin-producing Escherichia coli O157:H7 associated with contaminated salad leaves: epidemiological, genomic and food trace back investigations. Epidemiol Infect. 2018;146:187-96.

7. Karshima SN. Parasites of importance for human health on edible fruits and vegetables in Nigeria: a systematic review and metaanalysis of published data. Pathog Glob Health. 2018;112:47-55.

8. Coelho LM, Oliveira SM, Milman MH, Karasawa KA, Santos RP. Detecção de formas transmissíveis de enteroparasitas na água e nas hortaliças consumidas em comunidades escolares de Sorocaba, São Paulo, Brasil. Rev Soc Bras Med Trop. 2001;34:479-82.

9. Gupta N, Khan DK, Santra SC. Prevalence of intestinal helminth eggs on vegetables grown in wastewater-irrigated areas of Titagarh, West Bengal, India. Food Control. 2009;20:942-5.

10. Uhlig E, Olsson C, He J, Stark T, Sadowska Z, Molin G, et al. Effects of household washing on bacterial load and removal of Escherichia coli from lettuce and "ready-to-eat" salads. Food Sci Nutr. 2017;5:1215-20.

11. Olaimat AN, Holley RA. Factors influencing the microbial safety of fresh produce: a review. Food Microbiol. 2012;32:1-19.

12. Gregório DS, Moraes GF, Nassif JM, Alves MR, Carmo NE, Jarrouge MG, et al. Estudo da contaminação por parasitas em hortaliças da região Leste de São Paulo, Brasil. Sci Health. 2012;3:96-103.

13. Obala AA, Simiyu CJ, Odhiambo DO, Nanyu V, Chege P, Downing R, et al. Webuye Health and Demographic Surveillance systems baseline survey of soil-transmitted helminths and intestinal protozoa among children up to five years. J Trop Med. 2013;2013:734562.
14. Torgerson PR, Devleesschauwer B, Praet N, Speybroeck N, Willingham AL, Kasuga F, et al. World Health Organization estimates of the global and regional disease burden of foodborne parasitic diseases, 2010: a data synthesis. PLoS Med. 2015;12:e1001920.

15. Marine SC, Martin DA, Adalja A, Mathew S, Everts KL. Effect of market channel, farm scale, and years in production on midAtlantic vegetable producers' knowledge and implementation of Good Agricultural Practices. Food Control. 2016;59:128-38.

16 Brasil. Ministério da Saúde. Agência Nacional de Vigilância Sanitária. Resolução - RDC n 12, de 2 de janeiro de 2001. [cited 2018 Dec 18]. Available from: http://bvsms.saude.gov. br/bvs/saudelegis/anvisa/2001/res0012_02_01_2001.html

17. Castro-Ibáñez I, Gil MI, Allende A. Ready-to-eat vegetables: current problems and potential solutions to reduce microbial risk in the production chain. LWT Food Sci Technol. 2017;85:284-92.

18. Silva JP, Marzochi MC, Camillo-Coura L, Messias AA, Marques S. Estudo da contaminação por enteroparasitas em hortaliças comercializadas nos supermercados da cidade do Rio de Janeiro. Rev Soc Bras Med Trop. 1995;28:237-41.

19. Guilherme AL, Araújo SM, Falavigna DL, Pupulim AR, Dias ML, Oliveira HS, et al. Prevalência de enteroparasitas em horticultores e hortaliças de feira do produtor de Maringá, Paraná, Brasil. Rev Soc Bras Med Trop. 1999;32:405-11.

20. Guimarães AM, Alves EG, Figueiredo HC, Costa GM, Rodrigues LS. Frequência de enteroparasitas em amostras de alface comercializadas em Lavras, Minas Gerais. Rev Soc Bras Med Trop. 2003;36:621-3.

21. Nomura PR, Ferreira AR, Rafaelli RA, Augusto JG, Tatakihara VL, Custódio LA, et al. Estudo da incidência de parasitas intestinais em verduras comercializadas em feira livre e supermercado de Londrina. Semina Cien Biol Saude. 2015;36 Supl:209-14.

22. Falavigna LM, Freitas CB, Melo GC, Nishi L, Araújo SM, Falavigna-Guilherme AL. Qualidade de hortaliças comercializadas no noroeste do Paraná, Brasil. Parasitol Latinoam. 2005;60:144-9.

23. Belinelo VJ, Gouvêa MI, Coelho MP, Zamprogno AC, Fianco BA, Oliveira LG. Enteroparasitas em hortaliças comercializadas na cidade de São Mateus, ES, Brasil. Arq Cien Saude Unipar. 2009;13:33-6.

24. Yoshihara E. Enteropasitas em hortaliças consumidas cruas, Brasil. Pesq Tecnol. 2006;3:1-5.

25. Esteves FA, Figuerôa EO. Detecção de enteroparasitas em hortaliças comercializadas em feiras livres do município de Caruaru (PE). Rev Baiana Saude Publica. 2009;33:184-93.

26. Santos AO, Biondi GF. Qualidade das hortaliças comercializadas no Distrito Federal. Hig Aliment. 2009;23:138-41.

27. Alves AS, Cunha Neto A, Rossignoli PA. Parasitos em alface-crespa (Lactuca sativa L.), de plantio convencional, 
comercializada em supermercados de Cuiabá, Mato Grosso, Brasil. Rev Patol Trop. 2013;42:217-29.

28. Machado ER, Maldonade IR, Riquette RFR, Mendes VS, GurgelGonçalves R, Ginani VC. Frequency of Enteroparasites and Bacteria in the leafy vegetables sold in Brazilian public wholesale markets. J Food Prot. 2018;81:542-8.

29. Maciel DF, Gurgel-Gonçalves R, Machado ER. Ocorrência de parasitos Intestinais em hortaliças comercializadas em feiras no Distrito Federal. Rev Patol Trop. 2014;43:351-9.

30 Soares C, Cantos GA. Detecção de estruturas parasitárias em hortaliças comercializadas na cidade de Florianópolis, SC, Brasil. Rev Brasil Cien Farm. 2006;42:455-60.

31. Takayanagui OM, Capuano DM, Oliveira CAD, Bergamini AMM, Okino MHT, Castro e Silva AA, et al. Avaliação da contaminação de hortas produtoras de verduras após a implantação do sistema de fiscalização em Ribeirão Preto, SP. Rev Soc Bras Med Trop. 2007;40:239-41.

32. Ogbolu DO, Alli OA, Ogunleye VF, Olusoga-Ogbolu FF, Olaosun I. The presence of intestinal parasites in selected vegetables from open markets in southwestern Nigeria. Afr J Med Sci. 2009;38:319-24.

33. Maffei DF, Alvarenga VO, Sant'Ana AS, Franco BD. Assessing the effect of washing practices employed in Brazilian processing plants on the quality of ready-to-eat vegetables. LWT Food Sci Technol. 2016;69:474-81.
34. Brasil. Agência Nacional de Vigilância Sanitária. Cartilha sobre boas práticas para serviços de alimentação. $3^{\mathrm{a}}$ ed. Brasília: ANVISA; 2004.

35. Giovenzana V, Beghi R, Civelli R, Guidetti R. Optical techniques for rapid quality monitoring along minimally processed fruit and vegetable chain. Trends Food Sci Technol. 2015;46:331-8.

36. Alves EB, Conceição MJ, Silva VL, Fonseca AB, Leles D. What is the future of intestinal parasitic diseases in developing countries? Acta Trop. 2017;171:6-7.

37. Terio V, Bottaro M, Pavoni E, Losio MN, Serraino A, Giacometti F, et al. Occurrence of hepatitis A and E and norovirus GI and GII in ready-to-eat vegetables in Italy. Int J Food Microbiol. 2017;249:61-5.

38. Meireles A, Fulgêncio R, Machado I, Mergulhão F, Melo L, Simões M. Characterization of the heterotrophic bacteria from a minimally processed vegetables plant. LWT Food Sci Technol. 2017:85:293-300.

39. Brasil. Ministério da Saúde. Agência Nacional de Vigilância Sanitária. Resolução de Diretoria Colegiada - RDC n 275, de 21 de outubro de 2002. [cited 2018 Dec 19]. Available from: http://portal.anvisa.gov.br/documents/10181/2718376/ RDC_275_2002_COMP.pdf/fce9dac0-ae57-4de2-8cf9e286a383f 254 